\title{
UKRAINE IN THE CONTEMPORARY GEOPOLITICAL SPACE: TRENDS, RISKS AND THE CRISIS OF CHOICE
}

\section{Shchedrova H. P.}

\section{INTRODUCTION}

Contemporary geopolitics is characterized by the gradual domination of the political factor over the geographical factor, the increasing number of geopolitical actors, the fragmentation of international connections and relations, and the crisis prevention priorities that shift from the economic sphere to the security sphere. These aspects have affected Ukraine as well, which, albeit with varying intensity, had made its way into the global community since the moment it gained independence in 1991. The same period saw the beginning of Ukraine's inclusion as a sovereign state in the scientific analysis of the political world. Given its specific geographical location, Ukraine has always been and will remain a priority area of research in political geography and geopolitics. Classical theories based their interpretations of Ukraine on the interests of the influential global states; however, the development of the political sphere in our country has led to a shift in the direction of research - from "one of the countries of the post-socialist bloc" to "a country in the center of Europe."

In contemporary political science, Ukraine as a research subject provides enough reasons not only for contextual exploration as a part of studying the region or the zones of influence of geopolitical actors, but also for the analysis of internal political processes within our country, which result from or determine the course of international politics. Thus, the problem of Ukraine's geopolitical position is a focus of attention both for national researchers and for the leading scholars of the contemporary geopolitical concepts. Ukraine has been studied by Anthony Giddens and Roland Robertson in the context of globalism and glocalism; by Immanuel Wallerstein as a part of the world-systems analysis; by Jacques Attali and Francis Fukuyama within the neomondialism framework; by Paul Wolfowitz and Samuel P. Huntington from the perspective of neoAtlanticism; by Zbigniew Brzezinski from the perspective of the contemporary Anglo-American geopolitical school; by Aleksandr Dugin in the context of Eurasianism, etc. Despite the significant attention of 
scientific schools to the geopolitical transformations that involve Ukraine, as of today, a concentrated geopolitical model that would take into account both the internal potential of our country and the current conditions of the external political environment is still missing. In addition, the contemporary global politics with its determined priorities on the European continent provides us with an opportunity to make a certain generalization about the geopolitical nature of Ukraine.

Classic geopolitical trends - Atlanticism and mondialism continued with the corresponding neo-concepts which were substantiated as doctrines by contemporary authors, mostly from Western research schools. Other integral theoretical components of modern geopolitics are the concepts of contemporary Eurasianism, globalism, glocalism, and the world systems approach.

Beside the conceptualization of the Ukrainian factor in geopolitics, the questions of Ukraine's own geopolitical choice, its risks and its crisis potential also remain important. We need to comprehend not only on the concept of «geopolitical choice», but also the actualization of its contents beyond foreign policy or orientation, since we believe that these concepts are not essentially identical. It is important here to analyze Ukraine's path from attempts to regulate its foreign policy strategy and to personify the vision of its prospects of foreign partnership, from multiple attempts to determine the vector of its foreign policy, and towards formulating the state's actual geopolitical choice while taking into account the public opinion and the national interests.

The recent developments, with the turning point in 2013-14 and the unfolding of military events in the East of the country, have proved that the local-regional coordinates of Ukraine coincided in time and concurred with the interests of other global players, which subjected the country's roles to the more influential actors of the global politics. That is why the important research tasks are to determine both the place of Ukraine in contemporary geopolitics and the risks that accompany the state's external integration at a transitional stage in its development.

\section{Ukraine's Place in the Contemporary Schools of Geopolitical Concepts}

The modern stage of geopolitical research is characterized both by Ukraine's inclusion in the systemic scientific studies of the course of international politics and by the expanding subject field of theoretical 
concepts that take into account the transformation of the place and role of the Ukrainian state in the course of cross-border and global processes. In retrospect, the catalysts of these changes in political science were the collapse of the Soviet Union and Ukraine's search for optimal foreign policy strategy, which was not without internal contradictions and external pressure.

Neo-Atlanticism was enriched by the relevant features of cultural and religious identity, which in Samuel P. Huntington's interpretation represent the civilizational markers. In his original 1993 essay The Clash of Civilizations, the American researcher claimed that cultural fault lines would provide a constant source of conflict. ${ }^{1}$ This paper, which was later expanded into a book, identified Ukraine as a prototypical «cleft country», where Ukrainian and Russian-speaking populations co-exist, doomed to suffer. Samuel P. Huntington predicted that Moscow's foreign policies will aim to consolidate the whole Orthodox Christian community with Russia at its core. The theory emphasized the missionary purpose of uniting ethnic Russians scattered across all former Soviet republics ${ }^{2}$. In the context of the events in Eastern Ukraine, contemporary researchers emphasize that separatism and the threat of annexation of territories, predicted by Huntington in his time, are «a page in the Kremlin's playbook» ${ }^{3}$.

However, one of the most important factors that externally affect the processes in Ukraine, according to Samuel P. Huntington, is the civilizational dividing line in Europe, on which Ukraine is located. «This line runs along what are now the boundaries between Finland and Russia and between the Baltic states and Russia, cuts through Belarus and Ukraine separating the more Catholic western Ukraine from Orthodox eastern Ukraine, swings westward separating Transylvania from the rest of Romania, and then goes through Yugoslavia almost exactly along the line now separating Croatia and Slovenia from the rest of Yugoslavia», he says in The Clash of Civilizations ${ }^{4}$.

${ }^{1}$ Huntington S. The Clash of Civilizations. Foreign Affairs. Touchstone, 1993. URL: http://online.sfsu.edu/mroozbeh/CLASS/h-607-pdfs/S.Huntington-Clash.pdf.

2 Huntington S. The Clash of Civilizations and the Remaking of World Order. Harvard University Printed, 1996. URL: http://www.academia.edu/4610592/Samuel_ P_Huntington_The_Clash_of_Civilizations_and_the_Remaking_of_World_Order_1996.

${ }^{3}$ McKew Molly K., Maniati Gregory A. Putin's global ambitions could destabilize Europe. The Washington Post. March 18, 2014. URL: https://www.washingtonpost.com/ opinions/putins-global-ambitions-could-destabilize-europe/2014/03/18/69abb2a2-aec511e3-9627-c65021d6d572_story.html?utm_term=.84f30a2d8c78

${ }^{4}$ Huntington S. The Clash of Civilizations. Foreign Affairs. Touchstone, 1993. URL: http://online.sfsu.edu/mroozbeh/CLASS/h-607-pdfs/S.Huntington-Clash.pdf. 
A significant and distinguishing feature of Huntington's theory is the recognition of Ukraine as a country with certain civilizational - cultural, linguistic, religious - authenticity. Thus, Ukraine emerged not as a passive participant (or a hostage) of the global politics of influential actors, but as a party in the geopolitical process that has its own interests. An important clarification built into Huntington's theory is the consolidating value of civilization. That is, if civilizations as such do indeed exist, then in the case of the conflict between Ukraine and Russia this will become a restraining and moderating factor in the neutralization of the confrontation.

Paul Wolfowitz, another representative of neo-Atlanticism, developed one of the most influential concepts of US foreign policy at the time, which was dubbed the «Wolfowitz Doctrine». And although it was mostly about arguments justifying the United States domination in the postwar world, it still assigned an important role to the peaceful coexistence of the countries of the former USSR. «The U.S. has a significant stake in promoting democratic consolidation and peaceful relations between Russia, Ukraine and the other republics of the former Soviet Union», reads the doctrine. ${ }^{5}$ Wolfowitz wrote that the joint forces of the post-Soviet states "retain[ed] the most military potential in all of Eurasia." At the same time, the politician did not rule out that Russia might attempt to reincorporate the territories of the new independent states.

The neoconservative branch of classic Atlanticism was developed by Zbigniew Brzezinski, a representative of the Anglo-American school of geopolitics. The researcher did not only pay significant scientific attention to the problem of Ukraine from the global perspective, but also participated in active advocacy for our state in the context of the Revolution of Dignity events and the Donbas confrontation that followed. Back in the late 1990s, in his book The Grand Chessboard, Brzezinski described the unique role of Ukraine in the development of the postSoviet space; he said that the awakening of Ukrainians was the main piece of evidence for the imperial domination of a foreign nation (the Russians) ${ }^{6}$. Agreeing in part with Samuel P. Huntington, the researcher recognized that Ukraine, together with Azerbaijan, South Korea, Turkey

${ }^{5}$ Wolfowitz P. Defense Planning: Guidance. URL: https://www.archives.gov/files/ declassification/iscap/pdf/2008-003-docs1-12.pdf.

${ }^{6}$ Бжезінський 3. Велика шахівниця. Львів-Івано-Франківськ : Лілея-НВ, 2000. С. 9. 
and Iran, carried the role of a geopolitical axis that should soon develop the characteristics of geostrategic activity. His arguments supporting the important role of Ukraine in the Eurasian space are exhaustive and have been tested by the contemporary history.

In one of his last studies, Strategic Vision: America and the Crisis of Global Power, Zbigniew Brzezinski dedicated a whole chapter to Ukraine. And although the book was published back in 2012, its predictive value was confirmed by the further development of nation-building in Ukraine. Brzezinski states that Ukraine tends to support European values, and that Russia's relationship with Ukraine since Ukraine gained independence in 1991 had been prone to tension, just as its relationship with the West. The author emphasizes that Russia uses energy as an effective means of influencing and pressuring Ukraine into supporting policies that benefit the Kremlin. The political researcher highlights that the Russian Federation constantly tries to subjugate Ukraine, as it did with Belarus, but that it can only succeed in this "assuming America's decline [and] a passive European response ${ }^{7}$. Brzezinski's recommendations are, first of all, to have a dialogue (between Russia and the Atlantic West) and to implement consistent democratic reforms (in Ukraine and other countries of the former socialist bloc).

The tendencies of the transition from mondialism to its updated form of neomondialism are defined in the works by the American political scientist Francis Fukuyama and the French researcher Jacques Attali. Both of them wrote about a drastic shift in geopolitical paradigms which imply that global domination must be based solely on the criterion of economic progress and innovation which will ensure the survival of the civilization. One of the key differences between the two authors is their attitude to the concept of "the end of history." While for Francis Fukuyama it is the final destination of the humanity's ideological evolution and the universalization of Western liberal democracy as the final form of governance for the human society, ${ }^{8}$ for Jacques Attali it is the inevitable conflict between the old and the new order. ${ }^{9}$

${ }^{7}$ Brzezinski Z. Strategic Vision: America and the Crisis of Global Power. New York, 2012. URL: https://orientalreview.org/wp-content/uploads/2012/12/Brzezinski-Zbigniew.Strategic-Vision-America-and-the-Crisis-of-Global-Power.pdf.

${ }^{8}$ Fukuyama F. The End of History? The National Interest. 1989. № 16. P. 5.

${ }^{9}$ Attali J. Lignes d'horizon. Paris, 1990. 216 p. 
Fukuyama's first studies had only contextual relevance to Ukraine's problems; however, nowadays the American researcher does not only comment on the course of the political process in our state, but also makes appearances at educational events in Ukraine. In the period between 2016 and 2019, Francis Fukuyama gave a number of extended interviews to the leading Ukrainian media, and in spring 2019 in his comment to the Atlantic Council think tank the scholar emphasized once again the significant role played by Ukraine in Europe. "It is both a symbolic and a geopolitical role that makes Ukraine much more important than other post-Soviet or post-communist countries. It tried twice to break with its Soviet past, with its authoritarian, kleptocratic neighbor... The Russians perfectly understand how important it is that Ukraine does not become successful. Ukraine's success is creating a democracy with actual competition in politics or making order in its leadership", emphasized Francis Fukuyama ${ }^{10}$.

For the leader of neomondialism, Ukraine is an example of cohesiveness of an active community capable of becoming a driver of state-making. However, in Fukyama's opinion, without foreign support, the civil society in Ukraine becomes more passive and loses its mobilizing power.

An opposite opinion is proposed by the French expert Jacques Attali in his coverage and perception of the Ukrainian issue. He believes that it is wrong to use Russia's annexation of Crimea as a pretext for a confrontation between Europe and the Russian Federation. "We have never approved of the current Russian regime or of its international strategy. I'm talking about the West, and more precisely about Europe. And, for me, the interest of Europe is not to engage in a confrontation with Russia. On the contrary, we have to do everything to integrate our large Eastern neighbor into the sphere of the European law", wrote Attali in his personal blog in March 2014. ${ }^{11}$

The French researcher draws long-term historical analogies with similar situations in the EU countries, emphasizing that the right to self-

10 Френсіс Фукуяма: Україна грає величезну роль в Європі у всіх сенсах Atlantic Council. URL: https://zik.ua/news/2019/05/14/frensis_fukuyama_ukraina_ graie_velycheznu_rol_v_yevropi_u_vsih_sensah_1570941.

${ }^{11}$ Attali J. Ukraine: sont ils tous devenus fous? URL: http:// marcrousset.over-blog.com/ article-ukraine-sont-ils-tous-devenus-fous-selon-jacques-attali123114753.html. 
determination is considered to be one of the most inviolable European values. Thus, from the perspective of this self-determination, he also does not separate Ukraine, particularly the residents of Crimea, from the European community with all the rights that it possesses. These claims were not widely supported among the diplomats of the Old Europe, because the annexation of Crimea was the beginning of a long period of military aggression in Eastern Ukraine, which is still considered to be one of the greatest tragedies of the European civilization in the 21st century.

The contemporary concept of Eurasianism (neo-Eurasianism), which has been interpreted in the context of studying the role of Ukraine in international politics by Aleksandr Dugin, the founder of the contemporary Russian school of geopolitics, can be considered a polar opposite of the concept analyzed above. For Dugin, Ukraine is one of the fronts of the "Great War of Continents", that is, the war between Atlanticists and Eurasianists. ${ }^{12}$ The Russian researcher defines several scenarios for the contemporary Ukraine:

- federalization of the state by conducting a referendum;

- splitting Ukraine into two states;

- preserving the unified Ukraine (without Crimea) on the condition that it supports the Eurasianist policy - that is, the policy of the Kremlin.

We must note that none of Aleksandr Dugin's predictions manifested in real life. In turn, the author never established Ukraine's ideological and mental belonging to the Eurasian pole. The only thing that was substantiated in his theory was the particular interest of Eurasianists in gaining control over Ukraine.

Another component of the contemporary geopolitics is the concept of the globalized world that encompasses the spheres of the economy, education, cultural and informational development, and includes the political component, subordinating it to the modern conditions of globalization and globalism. The concept of "globalism" was first introduced into the scientific language in 1983 by the British researcher Roland Robertson. To clarify, in 1983, the author used the term "globality" for the first time in the title of one of his articles, ${ }^{13}$ and in

12 Дугин А. Началась Великая Война Континентов. Пражский Телеграф. 9 апреля 2014 г. URL: http://ptel.cz/2014/04/aleksandr-dugin-nachalas-velikaya-vojnakontinentov.

${ }^{13}$ Robertson R. Interpreting Globality. World Realities and International Studies. PA : Pennsylvania Council on International Education, 1983. P. 7-20. 
1985, he already provided a detailed definition of the concept of "globalization". Later, the researcher expounded the foundations of his concept of globalism in a dedicated study, where the term was defined as an interconnected system of political, ideological, economic, social, military and other measures that aim to establish at the global scale the domination of a certain socioeconomic, ideological doctrine. ${ }^{14}$

In one of his latest papers, Beyond the Discourse of Globalization, the founder of the concept of globalism considers the problem of Ukraine in the context of analyzing the crisis in Europe, which Robertson defined as a crisis of governance in search of new forms of world organization. "Europe, its allies, and its neighbours have drastically changed. I think here of such developments as a much more assertive Russia (under the authoritarian leadership of Putin), Russia's invasion of Ukraine, its annexation of Crimea and its ongoing threat to Baltic countries," the British researcher writes in his study. ${ }^{15}$ Ukraine, in our opinion, is considered to be an indicator of priorities which de facto demonstrate the negation of international law and disregard for ethical norms in the implementation of the good-neighborliness policy. In general, the conflict involving Ukraine in the center of Europe, from the perspective of the concept of globalism, has revealed a precedent when the global position did not manage to absorb the local one.

As we clarify the circumstances that came to hold Ukraine hostage in the globalized world, we should draw attention to the concept of glocalism, that is, the combination of globalization and localization in the development of the humanity. Roland Robertson himself, in his article European Glocalization in Global Context, characterizes Europe as the history of constant and multiple process of glocalization. The concept of glocalization in the case of Ukraine reveals the undeniable circumstances of the simultaneous spread of both global foreign policy strategies and local aspirations of particular social groups and pressure groups. Under these circumstances, state policies must have a certain set of alternatives and backup plans in case the international situation or the domestic confrontation escalates. We should note that under the current

${ }^{14}$ Robertson R. Globalization: Social Theory and Global Culture. Journal of World History. 1994. № 5/1. P. 159.

${ }^{15}$ Robertson R. Beyond the discourse of globalization. Glocalism: journal of culture, politics and innovation. 2015. № 1. P. 12. 
circumstances, Ukraine must take into account the ideological, the regional and the socioeconomic factors of glocalization.

The theses of the contemporary world-systems approach to geopolitics, pioneered by the American sociologist Immanuel Wallerstein, are equally relevant. The concept is based on the interregional and transnational division of labor which divides the world into core countries, semi-periphery countries and periphery countries. The leading Yale researcher has recently paid a lot of attention to the geopolitical processes related to Ukraine; moreover, our country has become the basis for Wallerstein's non-contextual research. In his article The Geopolitics of Ukraine's Schism, the scholar considers the question of determined influence on the course of political, and later also military scenarios in Ukraine, accusing the US of excessively intervening in European affairs, where Ukraine is "merely a convenient excuse... for a larger geopolitical division." "Let me therefore propose that Ukraine is merely a convenient excuse or proxy for a larger geopolitical division that has nothing whatsoever to do with its internal schism. What haunts [the US] is not a putative 'absorption' of Ukraine by Russia... What haunts [them] is a geopolitical alliance of Germany/France and Russia," claims Immanuel Wallerstein in his article. ${ }^{16}$ In addition, the author emphasizes the difficulty of choosing a strategic partner for Ukraine - between the European Union and the Russian Federation - in the circumstances of relatively equal support for both vectors of diplomatic orientation among the country's population.

Immanuel Wallerstein rules out the bipolar influence on Ukraine by only the US and the Russian Federation, and he also studies the role of contemporary Germany in this. We consider it necessary to note here that Wallerstein's world-systems paradigm in this context partially overlaps with the established opinion of the global diplomatic community about the situation in Ukraine. For example, the researcher calls the conflict in Eastern Ukraine a "quasi-civil war," and believes that the key actors who can positively affect the resolution of the military situation are Germany and the Russian Federation.

Tellingly, Ukraine features in the majority of the conceptual theses of the world-systems theory, but is left out of the key categorization of

${ }^{16}$ Wallerstein I. The Geopolitics of Ukraine's Schism. URL: https://www.iwallerstein.com/geopolitics-ukraines-schism. 
the countries into the core, the periphery and the semi-periphery. Given the essential features of the three types of states as defined by Immanuel Wallerstein, Ukraine at the present stage occupies an interstitial space between the periphery and the semi-periphery, because it still plays the role of a resource base for the so-called "world-economies"; however, its gravitation towards European values gradually causes it to depart from passive geopolitical participation.

Based on the analysis we conducted, we can argue that Ukraine today is one of the geopolitical centers which, due to its geographic location and intrinsic potential, and its social and resource-industrial potential in particular, affects the diplomatic priority-setting among the leading political actors on the international arena. An important aspect of this proposition is Ukraine's current departure from passive participation in the geopolitical process and the changes in our state's foreign advocacy that took place in late 2013 and early 2014.

We must note that Ukraine does not get the proper opportunities to realize its interests on the international map under the domination of any of the geopolitical concepts which we reviewed here. This is predicated on both the historic development of our state, which mostly took place in the conditions of subjugation and dependence, and on the incoherent and sometimes even contradictory strategies of realization of its foreign policy course. Therefore, one relevant task today is to construct a geopolitical model that would take into account the internal potential, needs and interests of Ukraine. In our opinion, the model must concentrate in its dominant features some aspects of the existing geopolitical concepts and approaches, in particular:

- development of the center with simultaneous support for the periphery given the heterogeneity of the regions (the world-systems approach);

- taking into account the internal contradictions in goal-setting and in the choice of the methods for realizing foreign policy strategies (the concept of glocalism);

- using the inclusivity of norms and political traditions of the globalized world to formulate the Ukrainian version of the implementation of European reforms (the theory of globalism); it is important here to combine the preservation of the authentic features of governance with the acquisition of the characteristics of democracy and 
competitiveness, particularly in the formation of a contemporary political class;

- recognizing Ukraine as a spatial axis of all civilizational transformations (neo-Atlanticism);

- support for democratic reforms in Ukraine as a part of the global process of modernization of the political systems of Western countries (neomondialism).

\section{The Crisis of Geopolitical Choice and Its Risks}

In one way or another, Ukraine has always featured and remains a priority both in conceptual views of geopolitics and on the maps of political interests of the major international players. At the same time, the Ukrainian state itself, since it gained independence in 1991, has pivoted in its foreign policy development and partnerships on multiple occasions, often exacerbating the discrepancy between its political statements, normative decisions and geopolitical orientation. The peculiarities of Ukraine's geographic location have always presented a choice between the West and the East. The choice concerns both politics, economy, and the values ingrained in the national orientation. The principles of geopolitical choice for Ukraine have usually been personified and affected by external influences, which were often not public.

I would be appropriate now not only to determine the factors and characteristics of the geopolitical choice, the circumstances of its crisis nature, but also to define the risks caused by contradictory political actions and decisions. At the same time, it is also worth analyzing the threats that Ukrainian instability poses to the international community, because the war in Donbas and the temporary loss of territories have led to unprecedented sanctions against the Russian Federation, and thus also created ad-hoc international coalitions and blocs. Another important aspect is the impact of global crises on Ukraine.

First of all, we should tackle the question of geopolitical choice, categorizing it. It is a subjective opinion that this concept is identical to the geopolitical orientation, because the latter is mostly defined by the priorities in choosing partners on the international arena, which is de facto done by the political elite. Geopolitical choice is a broader and more complex concept equivalent to the national interest. Thus, it is reasonable to interpret geopolitical choice as the external vector of national selfdetermination, formed with regard for the values and cultural reference 
points of the population, as well as for the priorities of economic development.

Since the moment Ukraine gained independence, its population mostly discussed foreign policy rather than geopolitics, limiting the latter to the directions of developing international connections. The first document that regulated these issues was the Decree of the Verkhovna Rada of Ukraine "On the key directions of Ukraine's foreign policy" of July 2, 1993. ${ }^{17}$ The document, which has expired by now, emphasized the importance of building partnerships with Western states, EU members and NATO; on the other hand, taking into account the particularities of Ukraine's historic development and its specific geopolitical and geoeconomic situation, the document defined the relations between Ukraine and Russia as dominant in terms of bilateral relations with the neighboring states. Further transformations of the foreign policy orientation were made without taking into account the opinion of the population, because the procedure for this was not institutionalized, and were articulated by the state's leaders, particularly by its presidents.

The dominants in the foreign policy preferences of the first two Ukrainian leaders, Leonid Kravchuk and Leonid Kuchma, were equally contradictory. On the one hand, in December 1991, Kravchuk signed the Belovezha Accords that liquidated the USSR and created the Commonwealth of Independent States; at the end of his presidency, in June 1994, he also signed the major Partnership and Co-operation Agreement with the EU, which became the foundation of Ukraine's European integration. On the other hand, the country's main strategic partner in that period was still Russia; Ukraine's collaboration with Russia as an independent state was established in February 1992. President Kuchma also made some dissonant diplomatic decisions which went down in history as the phenomenon of "multi-vector policy." These vectors were formalized in the documents signed by Leonid Kuchma: the Budapest Memorandum on the non-nuclear status of Ukraine and abandoning its nuclear weapons in exchange for sovereignty guarantees by the US, the UK and Russia (1994); the Charter on Special Partnership between Ukraine and NATO (1997); the Treaty on Friendship,

17 Про Основні напрями зовнішньої політики України : Постанова Верховної Ради України» від 02.07.1993 p. № 3360-XII. URL: https://zakon.rada.gov.ua/ laws/show/3360-12. 
Cooperation, and Partnership between Ukraine and the Russian Federation (1997); the Ukraine-NATO Action Plan that defined Ukraine's aspiration for membership in the alliance (2002); the Agreement on the Creation of the Single Economic Space with Russia, Belarus and Kazakhstan (2003).

The defining feature for Ukraine in 1991-2004 was its declared neutrality. First of all, it applied to foreign policy in the context of clear identification of geopolitical partners. However, according to the Ukrainian researcher Iryna Dudko, international relations in the early 1990s were not conducive to the establishment of Ukraine's neutral status - the tendency that requires that the neutrality of any country is established not only at the national but also at the global level did not manifest. ${ }^{18}$ The formal neutrality was also contingent on the subjective factor of Ukraine being identified on the international arena as «a part of Russia». In addition, Ukraine's coherent internal potential and diplomatic toolkit were perceivably insufficient for it to establish itself as an autonomous geopolitical actor. However, the thesis about Ukraine's prospects of becoming an influential state in the world, which was substantianted in the abovementioned parliamentary Decree on the foundations of foreign policy, remained unchanged.

The next Ukrainian president Viktor Yushchenko had an active proWestern state position. This is evident from his many diplomatic visits and negotiations about obtaining the NATO Membership Action Plan, his dialogue with the EU about the visa-free travel regime for Ukrainians, and so on.

The period of 2004-2010, associated with Viktor Yanukovych's presidency, is characterized both by the most considerable domestic crisis for Ukraine and, at the same time, by a consistent transition from implementing foreign orientation policies to formulating a geopolitical choice. Yanukovych signed the Kharkiv Agreements with Russia, prolonging the presence of the Black Sea Fleet of the Russian Federation in Crimea from 2017 until 2042 in exchange for a gas discount (2010). He also initiated the removal of a mention of Ukraine's aspiration to join the NATO from the laws, and added the norm about Ukraine's non-

18 Дудко І. Від декларацій до реалій зовнішньополітичного курсу України: 19912010 рр. Сучасна українська політика. Політики і політологи про неї. 2010. № 21. C. 209-223. URL: http://dspace.nbuv.gov.ua/bitstream/handle/123456789/26808/24Dudko.pdf?sequence $=1$. 
aligned status. ${ }^{19}$ And his refusal to sign the Agreement on association and a free trade zone with the European Union at the Eastern Partnership Summit in November 2013 became the beginning of the end of Yanukovych's presidency and caused the largest civic protest since Ukraine gained independence - the Euromaidan, which transformed into the Revolution of Dignity.

In view of the motives and the articulated demands of Euromaidan participants, this was the event that marked the formulation of a geopolitical choice in Ukraine, based on support for European values, integration of the Ukrainian state to the European Union, development of a Western-style market economy based on open competition. To confront the criticism questioning the objectivity of Euromaidan's representation, we present a number of survey results conducted in 2013-14. In November 2013, the results of IFAK Institute's public opinion survey showed that 58 percent of the surveyed Ukrainians were in favor of Ukraine joining the EU - 6 percent more support than in $2012 .{ }^{20}$ In 2013 , according to the findings of a survey conducted by the SOCIS Center for Sociological and Marketing Research and the Rating Sociology Group, 49.1 percent of the respondents would vote for Ukraine to join the European Union if there was a referendum; 29.6 percent would vote against it, while another 21.3 percent had not decided or were not ready to participate in such a referendum. Among those who have decided, the share of EU supporters is 62.4 percent. $^{21}$ The dynamics of public opinion shifts was demonstrated by the results of a joint study by Ilko Kucheriv Democratic Initiatives Foundation and the Razumkov Center. The percentage of supporters of Ukraine's European integration orientation grew from 49.1 percent in October 2011 to 50.5 percent in May 2014, with the highest support in the West of Ukraine (almost 88 percent) and the lowest support in the South (28 percent $)^{22}$.

19 Червоненко В. П'ять президентів України: чим вони запам'ятались. URL: https://www.bbc.com/ukrainian/features-48188256.

${ }^{20}$ DW-Trend: більшість українців - за вступ до EC. URL: https://www.dw.com/uk/dw-trend-більшість-українців-за-вступ-до-єс/а-17230854.

${ }^{21}$ Суспільно-політична ситуація в Україні: грудень 2013. URL: http://ratinggroup.ua/research/ukraine/obschestvennopoliticheskaya_situaciya_v_ukraine_dekabr_2013.html.

${ }_{22}$ Ставлення громадян до зовнішньополітичного вектору України: регіональний poзpi3. URL: https://dif.org.ua/article/stavlennya-gromadyan-do-zovnishnopolitichnogovektoru-ukraini-regionalniy-rozriz. 
The purely pro-European course of the newly elected president Petro Poroshenko also took shape as an extension of the social re-orientation. These geopolitical aspirations also determined such decisions as signing the Association Agreement with the EU, fulfilling the requirements for the visa-free regime for Ukraine, the termination of the Treaty on Friendship, Cooperation, and Partnership with Russia, and the formalization of the country's NATO and EU membership aspirations in the Constitution of Ukraine.

Going back to the substance of the thesis on geopolitical choice that was articulated above, we can state that it has taken the form of a meaningful aspiration in Ukraine in the period since 2014; the geopolitical choice in favor of the Western model of state-making became the foundation for the foreign vector of national self-determination and was supported by the choice of values and cultural reference points among the population. However, already in 2019, when Volodymyr Zelensky won the presidential election, Ukraine started getting contradictory messages from the state's leadership - about the need to negotiate with the Russian Federation on ending the war in Donbas, about a referendum on the questions of dialogue between Ukraine and Russia and on potential membership in the EU and NATO. These signals were naturally perceived as ambiguous by Western states, particularly because of the unclear prospects of the global reforms which became a kind of "entry ticket" to the united Europe for Ukraine. To sum up, we emphasize that the defining role under the conditions of Ukraine's current form of governance will be played by the results of the parliamentary election in late July 2019 and by the new configuration of political forces in the 9th Verkhovna Rada.

Thus, the political process in Ukraine, which started in 1991, shaped two tendencies - a normative and an empirical one - which contradicted each other for a long time and have developed shared characteristics only since 2014. The political-civilizational shift was caused by the formation of public civic demand for qualitatively new state policies, particularly foreign policies. Shifts happened in the public consciousness, too, displacing the tradition of the previous orientation's succession and conservation.

Recognizing the crisis markers and risks in the geopolitical vector of contemporary Ukraine, we will emphasize the following ones:

- In the situation of a democratic transformation of political institutions, high-quality modernization of the foreign policy 
orientation can be assured by the guaranteed implementation of reforms - their success directly affects the country's credibility in the eyes of the global community. Changes in the political elite often entail rejection of previous innovations, even if they were approved on the international arena.

- According to Article 106 of the Ukrainian Constitution, the president represents the state in international relations, supervises the foreign political activities of the state, holds negotiations and signs Ukraine's international agreements. ${ }^{23}$ Therefore, there is no guarantee here that the already selected and initiated foreign policy path will be effectively prolonged by the newly elected head of the state.

- The long-term absence of a fixed foreign policy vector of the country's development, the constant risk of being affected by more powerful international players, including in the form of pressure by force, have led to an unstable course of foreign policy and an urgent need for a quality upgrade in this sphere from the ideological and institutional perspective and in terms of personnel.

- The crisis of geopolitical choice also entails risks of adversely affecting the society and the economy. Shifting foreign policy priorities motivate the activation of migration processes, stall export-oriented manufacturing, destroy cross-border connections, can lead to ethnic conflicts, etc.

- Ukraine is still burdened by economic obligations to international financial institutions. Its geopolitical reorientation can decrease trust in the Ukrainian state, complicate further cooperation or even make it impossible. 2019 and 2020 will be the most challenging years for Ukraine in this context, because these are the years when, in addition to building new foundations for state policies, Ukraine has to pay back peak sums of its foreign debt.

Another sign of the crisis of geopolitical choice is the fragmented and selective implementation of the adopted laws which have determined the country's foreign policy priorities and regulated the means of their realization since 1991. The issue of European integration was normatively formalized for state purposes back in the 1990s; however, any actual shifts were implemented only in twenty years.

23 Конституція України : офіц. текст. URL: https://zakon.rada.gov.ua/laws/ show/254\%D0\%BA/96-\%D0\%B2\%D1\%80. 
In addition to the internal dialectics of geopolitical choice, Ukraine is also affected by the state of the global community as a whole, of its geostrategic imperatives, development trends and the formulated markers of instability, which influence Ukraine's place in the political world in one way or another.

The issues that are currently the focus of attention of the global community are wars or threats of war, economic stability, environmental security and so on. In general, control over the totality of these phenomena represents the contemporary understanding of the concept of "world order." The degree of concern and involvement of particular countries in resolving these issues is determined by the country's vulnerability to various risks. For example, some actions that make sense today include economic support for a weaker neighbor in order to avoid mass migration (the implementation of various grant projects for Ukraine by the neighboring EU member states), activation of military exercises if military operations are taking place in a neighboring country (the situation in Serbia, which brought its troops to full alert because of the operation in Kosovska Mitrovica), or organization of an emergency vaccination campaign because of a disease outbreak in a region across the border (the situation with the measles epidemic in the neighboring Romania and Ukraine). As we can see, in the past decade, Ukraine has played the role of both the active and the passive participant of such actions.

The beginning of 2019 was marked with the inclusion of instability in Ukraine in the top ten biggest global risks this year, according to the Eurasia Group consultancy firm. ${ }^{24}$ In general, Ukraine, with its troubles, took the ninth place out of ten selected by the experts. The key risks for the world this year, according to Eurasia Group, are:

- «bad seeds»: the world's decision-makers are so consumed with addressing the daily crises that arise that they're allowing a broad array of future risks to germinate;

- US-China relationship;

- cyberwar;

- European populism;

- the US domestic policy;

${ }^{24}$ Нестабільність в Україні - в десятці найбільших ризиків світу 2019 року Eurasia Group. URL: https://ua.krymr.com/a/nestabilnist-v-ukraini-u-top-ryzykiv-svitu-u2019/29697766.html. 
- «innovation winter»: analysts predict that the amount of financial and human capital in high tech will be reducing;

- «coalition of the unwilling»: the US president Donald Trump is sceptical of Washington's role in protecting the global legal order, and a number of world leaders support him in this;

- political risks in Mexico: the country's new president, Andres Obrador, actively pursues a policy of increasing the role of the state in the political cycle;

- the Ukrainian crisis;

- Nigeria is facing its most fiercely contested election since the country's transition to democracy in 1999.

Another danger "without a number," according to the experts, is the Brexit, the UK's expected exit from the European Union. Actually, the implications of Brexit as the event of the year in the global politics can also affect Ukraine. As a part of the EU, the UK has usually been on the side of those who advocate for the Ukrainian question in the context of preserving sovereignty and who support the European integration progress of Ukraine. Therefore, if the UK leaves the European Union in October 2019, Ukraine will lose an influential partner in the West. However, the country will probably remain a partner of the Ukrainian reforms, which have been highly evaluated by the British leadership. Further risks in the relations between Ukraine and the UK are associated with the figure of the country's future Prime Minister. Since Theresa May announced her resignation in May 2019, more than ten politicians have already expressed their willingness to run for the top government office; each of them has their own vision of the situation in Ukraine.

While the world's priorities before were about promoting economic interests, stability and development, now these priorities are competing with military and political affairs. For example, according to Die Welt's leading writer Holger Zschaepitz, the trade war, Brexit, the disorganized EU are the main geopolitical risks of the present, while the state of the economy is rather satisfactory. ${ }^{25}$

The phenomena that have been collectively recognized as the "Ukrainian crisis" include, according to Western analysts, the Russian military and political influence on the internal transformations in Ukraine,

25 Шара A. Die Welt: геополітичний прогноз на 2019, нова холодна війна між Росією та США. URL: https://tyzhden.ua/World/225422. 
the lobbying of the interests of pro-Russian politicians during the election campaign process, a religious confrontation. This state of affairs proves that domestic conflict and instability can be, and in the case of Ukraine are, a real geopolitical risk.

\section{CONCLUSIONS}

The analysis of geopolitical assessments of Ukraine from the perspective of various concepts allows us to state that:

- Ukraine lies not only on the spatial boundary between the West and the East, but also on the crossroads of the traditions of individualism and collectivism.

- Regardless of how we define the leading states in the global politics, Ukraine has been and remains a strategically important geopolitical unit for them, which is proven by the permanent place of the "Ukrainian issue" on the agenda of the most important meetings and events of major international organizations and unions (the EU, the UN, NATO, etc.).

- The trends and risks of the current situation in the region determine the importance of not just the West-East axis, but also the North-South axis. In particular, the important aspects here are the strategic support from the South (e.g. Turkey), the nominal neutrality of the near North (Belarus), the partnership of the further North (the Baltic countries).

- The implications of Ukraine's location on important transit routes, the country's powerful natural resources potential, and its shared borders with many countries, the majority of which have already successfully completed the European integration path, are, on the one hand, the availability of many options for its foreign policy, and on the other hand, the difficulty with implementing geopolitical strategies in the direction of European integration because of the country's borderline location.

In addition to including Ukraine in the modern geopolitical theories, when our study started to rely on the factors of civilizational belonging and the state's political choice rather than on the geographic component, Ukraine itself became a prominent and significant element of the contemporary geopolitical space. The "actor" category has been avoided on purpose, since we often meant passive participation and the factor of dependence. First, this is about Ukraine's sensitivity and vulnerability to global crisis phenomena. Second, Ukraine is itself experiencing a deep crisis of geopolitical choice, which has only exacerbated with the change 
of government in spring 2019. Third, instability in Ukraine in recent years has been recognized as one of the ten urgent risks for the world.

As for the risks caused by the lack of stable geopolitical choice, they are the incoherency and contradictory nature of the country's foreign policy orientation, and the difficulty of forming a positive international image for the country because of its frequently shifting policy priorities after each electoral period. Other risks still include the constant threat of foreign pressure, particularly by military means, that affects the implementation of domestic reforms. In addition, an urgent issue for Ukraine is the probability of complications with fulfilling its financial obligations. At the same time, the fact remains that the leading geopolitical actors are interested in preserving their capacity to affect Ukraine as the axis where the interests of the West and the East collide, as an embodiment of civilizational development, and as one of the most optimal transit routes of Europe and Asia.

\section{SUMMARY}

The article analyses the role and place of Ukraine in contemporary geopolitical concepts, determines the trends and priorities for Ukraine in the context of global theories (globalism, glocalism, world-systems approach, contemporary Anglo-American school of geopolitics), contemporary forms of Atlanticism and mondialism, and the polar opposite of Eurasianism. Based on the conducted analysis, it is proposed that today Ukraine is one of the geopolitical centers which, due to a number of internal factors, affects the diplomatic prioritysetting among the leading political actors on the international arena. The article proposes a geopolitical model that is based on the characteristics of existing models and takes into account the intrinsic potential, needs and interests of Ukraine. It makes a distinction between the concepts of "foreign policy orientation" and "geopolitical choice," where the latter is defined as the external vector of national self-determination formed with regard for the values and cultural reference points of the population, as well as for the priorities of economic development. Given the lack of a stable strategy of foreign policy implementation and the contradictory nature of the declared and the implemented geopolitical goals, the article concludes that there is a crisis of geopolitical choice in Ukraine. It entails the risks of foreign 
pressure, loss of international credibility, financial insolvency in the context of fulfilling the country's debt obligations, etc.

\section{REFERENCES}

1. Huntington S. The Clash of Civilizations. Foreign Affairs. Touchstone, 1993. URL: http://online.sfsu.edu/mroozbeh/CLASS/h-607pdfs/S.Huntington-Clash.pdf.

2. Huntington S. The Clash of Civilizations and the Remaking of World Order. Harvard University Printed, 1996. URL: http://www.academia.edu/4610592/Samuel_P_Huntington_The_Clash_of _Civilizations_and_the_Remaking_of_World_Order_1996.

3. McKew Molly K., Maniati Gregory A. Putin's global ambitions could destabilize Europe. The Washington Post. March 18, 2014. URL: https://www.washingtonpost.com/opinions/putins-global-ambitions-coulddestabilize-europe/2014/03/18/69abb2a2-aec5-11e3-9627-c65021d6d572_ story.html?utm_term $=.84 \mathrm{f} 30 \mathrm{a} 2 \mathrm{~d} 8 \mathrm{c} 78$

4. Huntington S. The Clash of Civilizations. Foreign Affairs. Touchstone, 1993. URL: http://online.sfsu.edu/mroozbeh/CLASS/h-607pdfs/S.Huntington-Clash.pdf.

5. Wolfowitz P. Defense Planning: Guidance. URL: https://www.archives.gov/files/declassification/iscap/pdf/2008-003docs1-12.pdf.

6. Бжезінський 3. Велика шахівниця. Львів-Івано-Франківськ : Лілея-НВ, 2000. С. 9.

7. Brzezinski Z. Strategic Vision: America and the Crisis of Global Power. New York, 2012. URL: https://orientalreview.org/wp-content/ uploads/2012/12/Brzezinski-Zbigniew.-Strategic-Vision-America-and-theCrisis-of-Global-Power.pdf.

8. Fukuyama F. The End of History? The National Interest. 1989. № 16. P. 5.

9. Attali J. Lignes d'horizon. Paris, 1990. 216 p.

10. Френсіс Фукуяма: Україна грає величезну роль в Європі у всіх сенсах - Atlantic Council. URL: https://zik.ua/news/2019/05/ 14/frensis_fukuyama_ukraina_graie_velycheznu_rol_v_yevropi_u_vsih_ sensah_1570941.

11. Attali J. Ukraine: sont ils tous devenus fous? URL: http://marcrousset.over-blog.com/article-ukraine-sont-ils-tous-devenusfous-selon-jacques-attali-123114753.html. 
12. Дугин А. Началась Великая Война Континентов. Пражский Телеграф. 9 апреля 2014 г. URL: http://ptel.cz/2014/04/aleksandrdugin-nachalas-velikaya-vojna-kontinentov.

13. Robertson R. Interpreting Globality. World Realities and International Studies. PA : Pennsylvania Council on International Education, 1983. P. 7-20.

14. Robertson R. Globalization: Social Theory and Global Culture. Journal of World History. 1994. № 5/1. P. 159.

15. Robertson R. Beyond the discourse of globalization. Glocalism: journal of culture, politics and innovation. 2015. № 1. P. 12.

16. Wallerstein I. The Geopolitics of Ukraine's Schism. URL: https://www.iwallerstein.com/geopolitics-ukraines-schism.

17. Про Основні напрями зовнішньої політики України : Постанова Верховної Ради України» від 02.07.1993 р. № 3360-XII. URL: https://zakon.rada.gov.ua/laws/show/3360-12.

18. Дудко I. Від декларацій до реалій зовнішньополітичного курсу України: 1991-2010 pp. Сучасна українська політика. Політики і політологи про неї. 2010. № 21. С. 209-223. URL: http://dspace.nbuv.gov.ua/bitstream/handle/123456789/26808/24Dudko.pdf?sequence $=1$.

19. Червоненко В. П'ять президентів України: чим вони запам'ятались. URL: https://www.bbc.com/ukrainian/features-48188256.

20. DW-Trend: більшість українців - за вступ до EC. URL: https://www.dw.com/uk/dw-trend-більшість-українців-за-вступ-до-єс/ a-17230854.

21. Суспільно-політична ситуація в Україні: грудень 2013. URL: http://ratinggroup.ua/research/ukraine/obschestvenno-politicheskaya_situa ciya_v_ukraine_dekabr_2013.html.

22. Ставлення громадян до зовнішньополітичного вектору України: регіональний розріз. URL: https://dif.org.ua/article/ stavlennya-gromadyan-do-zovnishnopolitichnogo-vektoru-ukrainiregionalniy-rozriz.

23. Конституція України : офіц. текст. URL: https://zakon.rada.gov.ua/laws/show/254к/96-вр.

24. Нестабільність в Україні - в десятці найбільших ризиків світу 2019 року - Eurasia Group. URL: https://ua.krymr.com/a/ nestabilnist-v-ukraini-u-top-ryzykiv-svitu-u-2019/29697766.html. 
25. Шара A. Die Welt: геополітичний прогноз на 2019, нова холодна війна між Росією та CША. URL: https://tyzhden.ua/ World/225422.

Information about the author: Shchedrova H. P. Doctor of Political Sciences, Professor, Head of the Department of Political Science and International Relations, Alfred Nobel University 18, Sicheslavska Naberezhna str., Dnipro, 49000, Ukraine 